\title{
The Risk Factor that Affect Children Diarrhea in The Island of Java 2013 (Riskesdas 2013 Data Analysis)
}

\author{
Dian Perwita Sari \\ BPS-Statistics of Indonesia \\ dian.sari@bps.go.id \\ Budyanra \\ Institute of Statistics, Jakarta, Indonesia \\ budy@stis.ac.id \\ (Corresponding author)
}

\begin{abstract}
Diarrhea is the biggest cause of infant and child death in Indonesia. In 2013, Indonesian Ministry of Health stated that children diarrhea incidence was still high and rated as public health problem accounting for 6.7 per cent. Two of five provinces with the highest incidence of infant diarrhea in Indonesia was located in the island of Java, even though Java has the biggest achievement in infant and child healthcare coverage as well as the physical quality of drinking water and improved sanitation over the national. Based on these facts, the purpose of this study was to identify risk factors that affect the incidence of children diarrhea in Java 2013. Binary logistic regression was used to statistical analysis with incidence of children diarrhea as response variable while the explanatory variables are age, nutritional status, level maternal education, maternal age, maternal behavior of washing hands, access to sources of drinking water, access to sanitation facilities and household density. The source of data was Riskesdas 2013. The results of this study showed that all the explanatory variables: age, nutritional status, maternal education level, maternal age, maternal behavior of washing hands, access to sources of drinking water, access to sanitation facilities and household density significantly affect the incidence of children diarrhea.
\end{abstract}

Keywords: children diarrhea, binary logistic regression, Riskesdas 2013.

\section{Introduction}

Indonesia has signed the "Millennium Declaration" which contains a commitment to accelerate human development and eradicate poverty. One of the Millennium Development Goals (MDGs) included in the fourth goal is to decrease Child Mortality Rate (CMR) to 32 per 1,000 live births in the period 1990-2015. CMR is an indicator which is directly relate to the child survival target and reflect the condition of social, economic, and the neighborhood of the children including their health maintenance (BPS, 2012). This commitment continues into SDGs which targeted a decline until 25 per 1,000 live births in the period 2016-2030 (RakorpopKemenkes RI, 2015). However, until the year of 2012, the number of CMR had just reached 40 per 1,000 live births. By this condition, it had been predicted that declining child mortality to 25 per 1000 live births can't be reached in the end of the 2015 and still need a special concern (Bappenas, 2015).

Based on the report of Riset Kesehatan Dasar (Riskesdas) 2007, the largest cause of infant and child death in Indonesia was diarrhea. Diarrhea accounted for $31.4 \%$ of infant (0-12 months) death and 25.2\% of child (0-59 months) death (Kemenkes RI, 2014). Until 2013, incidence rate of children diarrhea in Indonesia was still high, reached 6.7 percent (Depkes 
RI, 2015). DKI Jakarta and Banten were two of five provinces with highest rate of children diarrhea incidence reaching $8.9 \%$ and $8.1 \%$ respectively. Surprisingly, these two provinces were located in island of Java that had more health infrastructure compared to other regions (Siregar and Nely, 2005).

Judging from the infant and child health care coverage, access to improved sanitation and the good quality of drinking water, Java had been estimated to have a splendid achievement compare to other island. However, the incidence rate of children diarrhea based on health worker diagnosis or symptoms still the highest exceeding the national percentage. (Figure 1).

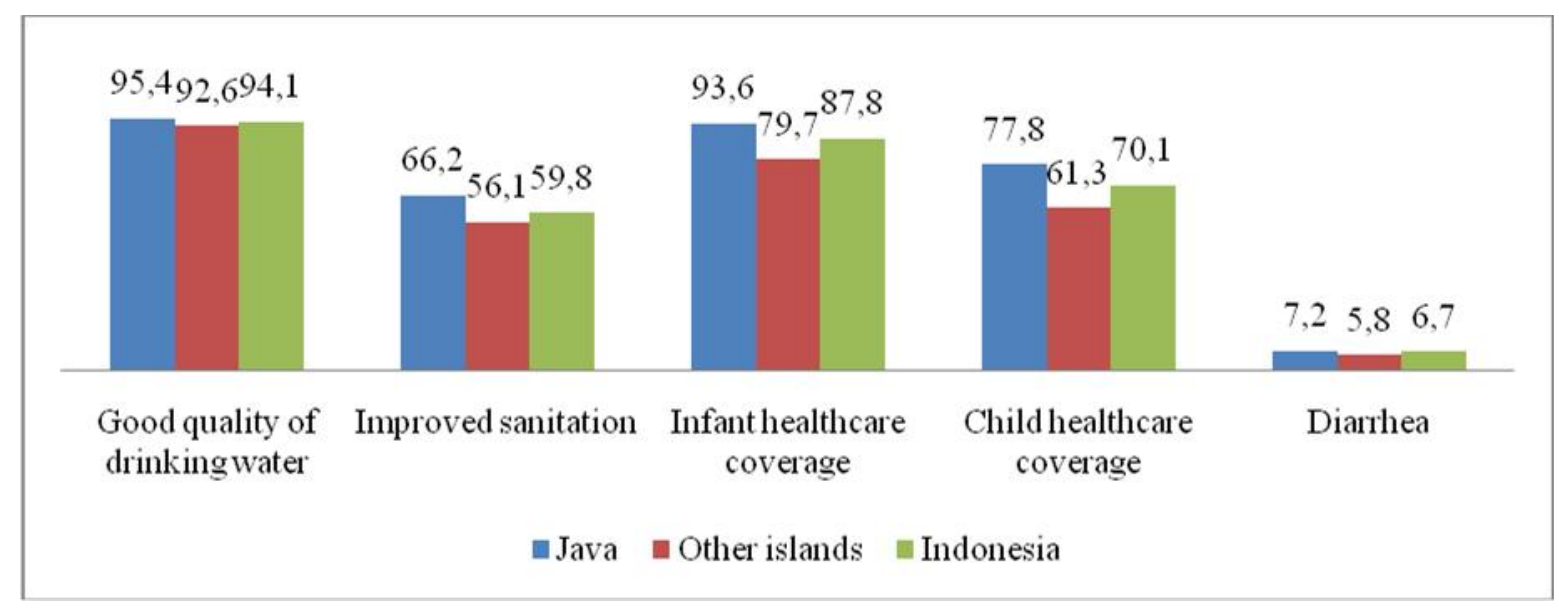

Figure 1. Environmental Health Achievement, Health Care Coverage and Incidence Rate of Child Diarhea in Indonesia 2013 (Riskesdas 2013 publication (in processed).

Based on the facts and data, the risk factor caused children diarrhea in Java need to be investigated. The purpose of this study is to give an overview about the causes of children diarrhea in Java through descriptive statistics using cross tabulation, and identifying the variables that affects children diarrhea in Java as well as the tendency of each variable to affect children diarrhea through inferential statistics by binary logistic regression.

\section{Literature Review}

WHO (2013) defined diarrhea as the passage of three or more loose or liquid stools per day (or more frequent passage than is normal for the individual). The common causes of diarrhea were by infection and poison (Kemenkes RI, 2011). Exceed fluid loss in diarrhea will cause dehydration that lead to child's death in a short time (Widjaja, 2001). Dehydration in adults rarely lead to death because children children excrete the volume of water greater than in adults or lose water proportionally larger (Yusuf, 2012).

According to Notoatmodjo (2010), the risk factors are factors or circumstances that affect the development of a particular disease or health status. There are two kinds of risk factors, the risk factors that are derived from the organism itself (intrinsic factors) such as gender and age, behavior and nutritional status; and risk factors that are derived from the environment (risk factors extrinsic). Hendrik L. Blum (Effendy, 1998) also said that there are four factors that

2 Received March 10, 2017; Revised March 29, 2017; Accepted April 21, 2017 
affect people's health status: environmental, behavioral, health services and genetic. These factors affect one another, which adversely affects the health status of individuals, families and groups as well as society as a whole (Effendy, 1998).

Adisasmito (2007) stated that the risk factors associated with diarrheal disease were widely studied by academics are environmental factors, child factors, maternal factors and sociodemographic factors. Research conducted by Irianto, et al. (1996) in the journal entitled "Factors Influencing on the Incidence of Diarrhoea Among Children Under Five Years of Age" shows that the socio demographics factors, parent's education, age of children, source of drinking water, type of latrine, distance between the well and septic tank, and population density all have influence in diarrhea. Moreover, the highest risk occurred among household which have toilet facility without septic tank. Further research conducted by Sinthamurniwaty in 2006 in a thesis entitled "Risk Factors of Acute Diarrhea Occurrence On Children Under FiveYears (Case Study In Semarang Regency)" showed that risk factors that influence diarrhea on children under five years based on multivariate analysis is 0-24 months children, low nutrition status, low education nursemaid and they who do not use clean water source.

Binary logistic regression is a mathematical modeling approach that can be used to explain the relationship between several explanatory variables to a dichotomous response variable (Kleinbaum Klein, 2010). There are two primary reasons for choosing the logistic distribution. First, from mathematical point of view, it is an extremely flexible and easily used function, and second, it lends itself to a clinically meaningful expression (Hosmer and Lemeshow, 2000). The response variable were categorized as $Y=1$ as a presence of event and $\mathrm{Y}=0$ as an absence of event. According to Ghozali (2001) and Gujarati (2003), logistic regression analysis technique does not require the assumption of normality and ignore heteroscedasticity (Febrianty, 2013).

According to Hosmer and Lemeshow (2000), to fit the logistic regression model to a set of data, we should estimate the values of the unknown parameters using the maximum likelihood method. The maximum likelihood method is the general method of estimation that leads to the least squares function under the linear regression model. A goodness of fit test in this study was assessed using Hosmer and Lemeshow test to prove whether the predicted values are an accurate representation of the observed values in an absolute sense. Afterward, simultant test usinglikelihood ratio test for overall significance of the $\mathrm{p}$ coefficients for the explanatory variables in the model is performed to determine whether the explanatory variables in the model are "significantly" related to the response variable. This test is based on the statistic G. Finally, to conclude that any or all of the coefficients are "significantly" related to the response variable, Wald test statistics should be done.

\section{Method}

This study used data from Riset Kesehatan Dasar (Riskesdas) 2013 that was conducted in May-June 2013 by Indonesian Ministry of Health. The focus of this study is children aged 059 months at the time of interview and located in Java Island. From 82,666 children under five in Indonesia that had been chosen as samples, 21,857 were located in Java Island. To avoid dependency, if there were more than one child aged 0-59 months, the last child is used as a subject of this study. After exclude some data that did not meet the criteria (such as the households did not answer the variables of interest in this study or the answers were hardly categorize into group because the answer was "Do not know"), the eligible sample that can be

3 Received March 10, 2017; Revised March 29, 2017; Accepted April 21, 2017 
studied is 17,942 children.

The response variable used in this study was the incidence of children diarrhea within one last month. In this study, respondent stated had diarrhea if they have been diagnosed by health professionals (doctors / nurses / midwives) had diarrhea or haven't diagnosed with diarrhea by health professionals but experiencing some symptoms of diarrhea. The incidence of diarrhea in Riskesdas questionnaires obtained from Riskesdas 2013 for individuals (RKD13.IND) number A03 and A04. The explanatory variables used were age of child, nutritional status of child, education level of mother, age of mother, hand washing practice of mother, access to sources of drinking water, access to sanitation, and household density. The statistical program used for inferential analysis purpose was SPSS 20 while tables and graphs using both SPSS 20 and Microsoft Excel 2010.

\section{Result}

About $12.1 \%$ children under five (aged 0-59 months) in Java had suffer diarrhea. DKI Jakarta was accounted to be a province with the largest incidence of children diarrhea that is $13.7 \%$ while Yogyakarta is had fewest incidents children diarrhea that is $10.7 \%$ (Figure 2).

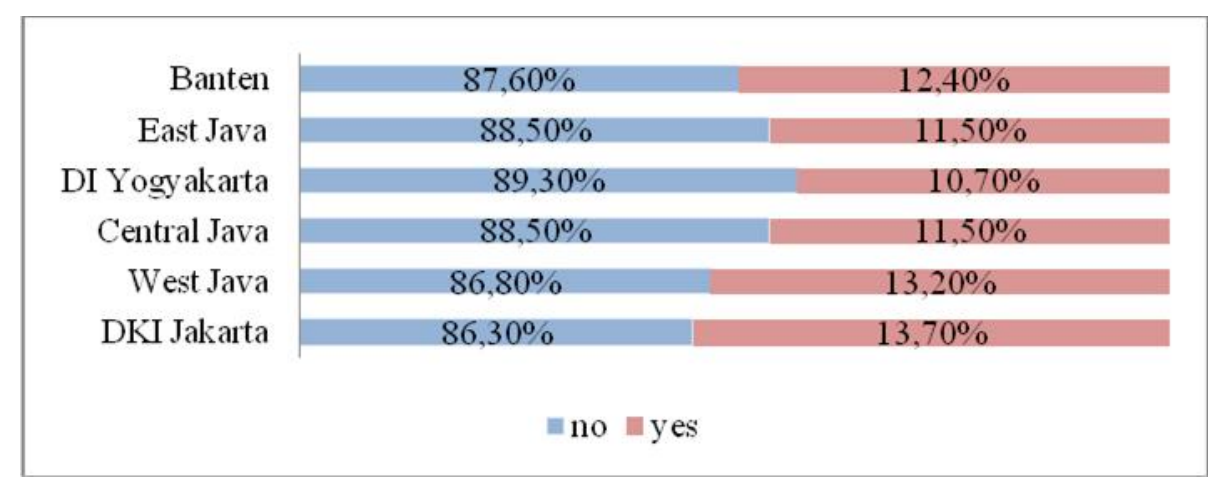

Figure 2. Diarrhea among children in Java According to Province 2013 (Riskesdas Raw Data 2013 (in processed)

The major characteristics of children in Java were aged 25-59 months and had a good nutritional status. The mother of the children in Java characteristically low educated ( $\leq$ junior high school), aged $>30$ years, and had done hand washing properly. The major characteristics of dwelling environment of children were have improved access to source drinking, improved access to sanitation and living in sparse household density ( $\geq 8 \mathrm{~m}^{2}$ per person) (Table 1). 
Table 1

Characteristics of children in Java island in 2013

\begin{tabular}{lll}
\hline Variables & Category & $\begin{array}{l}\text { Percentage } \\
(\%)\end{array}$ \\
\hline Age of child & 0-24months & 42.8 \\
& 25-59months & 57.2 \\
Nutritional status of & Poor & 4.3 \\
child & Fair & 12.6 \\
& Good & 83.0 \\
Educational level of & Low (<=Junior High School) & 62.8 \\
mother & High (>=Senior High School & 37.2 \\
Age of mother & $<=30$ years old & 45.6 \\
& $>30$ years old & 54.4 \\
Handwashing practice & Practice hand washing properly & 57.2 \\
of mother & Practice hand washing improperly & 42.8 \\
Access to source of & Improved & 72.3 \\
drinking water & Unimproved & 27.7 \\
Access to sanitation & Improved & 64.1 \\
& Unimproved & 35.9 \\
Household density & Dense (<8m²/person) & 14.6 \\
& Sparse ( $\geq 8 \mathrm{~m}^{2} /$ person) & 85.4 \\
\hline
\end{tabular}

Source: Riskesdas Raw Data 2013 (processed)

Most of children in Java that suffered with diarrhea were aged 0-24 months (14\%), had poor nutritional status $(14.4 \%)$, had low educated mother $(13.6 \%)$, aged $\$ 30$ years $(13.5 \%)$, and practice hand washing improperly (13.8\%), living in households that have unimproved source of drinking water (13.9\%), have unimproved sanitation access (14.2\%), and lived in dense household (14.9\%) (Table 2).

Goodness of fit test was done by using Hosmer and Lemeshow test. Based on the result, the value of $\bar{C}$ test statistic is 3.873 . By comparing the $\bar{C}$ value with the value of $\chi_{0,05 ; 8}^{2}$ table $(=$ 15.507), we failed to reject the null hypothesis (H0) $\left(\tilde{C}<\chi_{0,05 ; 8}^{2}\right)$, so it can be concluded that binary logistic regression model was appropriate in predicting observations (Table 3 ). The result of simultant test generated the $p$ valueof 0.00 concluded that at least one of the independent variables was significantly correlated with the children diarrheaincidence (Table 4). Partial test showed that all the variables in this study was significantly related with the children diarrhea incidence (Table 5). 
Table 2

Children diarrhea based on child's characteristic

\begin{tabular}{|c|c|c|c|}
\hline \multirow[b]{2}{*}{ Variable } & \multirow[b]{2}{*}{ Category } & \multicolumn{2}{|c|}{$\begin{array}{c}\text { Incident Children } \\
\text { diarrhea }\end{array}$} \\
\hline & & yes & no \\
\hline \multirow[t]{2}{*}{ Age of child } & 0-24months & $14.0 \%$ & $86.0 \%$ \\
\hline & 25-59months & $10.7 \%$ & $89.3 \%$ \\
\hline \multirow{3}{*}{$\begin{array}{l}\text { Nutritional status of } \\
\text { child }\end{array}$} & Poor & $14.4 \%$ & $85.6 \%$ \\
\hline & Fair & $13.3 \%$ & $86.7 \%$ \\
\hline & Good & $11.8 \%$ & $88.2 \%$ \\
\hline \multirow{2}{*}{$\begin{array}{l}\text { Educational level } \\
\text { of mother }\end{array}$} & Low & $13.6 \%$ & $86.4 \%$ \\
\hline & High & $9.6 \%$ & $90.4 \%$ \\
\hline \multirow[t]{2}{*}{ Age of mother } & $<=30$ years old & $13.5 \%$ & $86.5 \%$ \\
\hline & > 30 years old & $10.9 \%$ & $89.1 \%$ \\
\hline \multirow{2}{*}{$\begin{array}{l}\text { Handwashing } \\
\text { practice of mother }\end{array}$} & Practice hand washing properly & $10.9 \%$ & $89.1 \%$ \\
\hline & Practice hand washing improperly & $13.8 \%$ & $86.2 \%$ \\
\hline \multirow{2}{*}{$\begin{array}{l}\text { Access to source of } \\
\text { drinking water }\end{array}$} & Improved & $11.4 \%$ & $88.6 \%$ \\
\hline & Unimproved & $13.9 \%$ & $86.1 \%$ \\
\hline \multirow[t]{2}{*}{ Access to sanitation } & Improved & $10.9 \%$ & $89.1 \%$ \\
\hline & Unimproved & $14.2 \%$ & $85.8 \%$ \\
\hline \multirow[t]{2}{*}{ Household density } & Dense (<8m²/person) & $14.9 \%$ & $85.1 \%$ \\
\hline & Sparse ( $>8 \mathrm{~m}^{2} /$ person $)$ & $11.6 \%$ & $88.4 \%$ \\
\hline
\end{tabular}

Source: Riskesdas Raw Data 2013 (processed)

Table 3

Goodness of fit test result (Hosmer and Lemeshow Test)

\begin{tabular}{|c|c|c|c|}
\hline Step & Chi-square & $\mathrm{df}$ & Sig. \\
\hline (1) & (2) & (3) & (4) \\
\hline 1 & 3.873 & 8 & .868 \\
\hline
\end{tabular}

Table 4

Simultant test result (Omnibus Tests of Model Coefficients)

\begin{tabular}{lllll}
\hline & & Chi-square & df & Sig. \\
\hline Step 1 & Step & 201.052 & 9 & .000 \\
& Block & 201.052 & 9 & .000 \\
& Model & 201.052 & 9 & .000 \\
\hline
\end{tabular}


Table 5

Partial test result (Variable in Equation)

\begin{tabular}{|c|c|c|c|}
\hline $\begin{array}{c}\text { Variabel } \\
\text { (1) }\end{array}$ & $\begin{array}{c}\overrightarrow{\boldsymbol{\beta}} \\
(2)\end{array}$ & $\begin{array}{c}p \text {-value } \\
\text { (3) }\end{array}$ & $\begin{array}{c}\exp (\overline{\boldsymbol{\beta}}) \\
(4)\end{array}$ \\
\hline Age of child $\left(\mathrm{x}_{1}\right)$ & .283 & $.000 *$ & 1.327 \\
\hline Fair nutritional status $\left(\mathrm{x}_{21}\right)$ & .147 & $.030 *$ & 1.159 \\
\hline Poor nutritional status $\left(\mathrm{x}_{22}\right)$ & .211 & $.047^{*}$ & 1.234 \\
\hline $\begin{array}{l}\text { Mother's educational status } \\
\left(\mathrm{x}_{3}\right)\end{array}$ & .322 & $.000^{*}$ & 1.380 \\
\hline Age of mother $\left(\mathrm{x}_{4}\right)$ & .201 & $.000 *$ & 1.223 \\
\hline $\begin{array}{l}\text { Mother's handwashing } \\
\text { unproperly }\left(\mathrm{x}_{5}\right)\end{array}$ & .200 & $.000^{*}$ & 1.222 \\
\hline $\begin{array}{l}\text { Improved source of drinking } \\
\text { water }\left(\mathrm{x}_{6}\right)\end{array}$ & .198 & $.000^{*}$ & 1.219 \\
\hline Improved sanitation $\left(\mathrm{x}_{7}\right)$ & .153 & $.002 *$ & 1.166 \\
\hline KepadatanHunian $\left(\mathrm{x}_{8}\right)$ & .170 & $.006 *$ & 1.186 \\
\hline Constant & -2.686 & $0.000^{*}$ & .068 \\
\hline
\end{tabular}

*: significant at alpha $=0.05$

The odds of developing children diarrhea among children in the age group 0-24 months were 1.327 times higher than those children whose age was greater than 25 months. The odds of developing children diarrhea among children whose in poor and fair nutritional status 1.159 times and 1.234 times higher than those children who whose in good nutritional status, respectively. The odds of developing children diarrhea among children whose mother had low educational status 1.380 times higher than children whose mother had high educational status. The odds of developing children diarrhea among children whose mother aged $<=30$ years old were 1.223 times higher than those children whose mother aged $>30$ years old. The odds of developing children diarrhea among children whose mother had practiced handwashing improperly 1.222 higher than children whose mother had practiced handwashing properly.

The odds of having diarrhea in children living in households with unimproved source of drinking water were 1.219 times higher than in children living in households with improved source of drinking water. The odds of having diarrhea in children living in households with unimproved sanitation were 1.16 times higher than children living in households with improved sanitation. The odds of having diarrhea in children living in dense household were 1.186 times higher than in children living in sparse household. 


\section{Discussion}

The childhood diarrhea in Java happened among children aged 0 to 24 months, had a poor nutritional status, had low education mother, had mother aged 30 years and below, had mother whose practice hand washing improperly, living in households which had access to unimproved drinking water sources, had access to unimproved sanitation and lived in dense household. All the variables: age of child, nutritional status of child, educational level of mother, age of mother, hand washing practice of mother, access to sources of drinking water, access to sanitation and household density significantly proved related to childhood diarrhea in Java.

The higher risk of children aged 0-24 months to suffer diarrhea than children aged 25-59 months was because the immune system of younger children is low and become more suspect to some infections such as diarrhea. In addition, there were some children who no longer breastfeeding so that the immunity level become low (Shintamurniwaty, 2006). This applied also to children who had poor nutritional status. The lower the nutritional status, the higher the risk suffered diarrhea. This can be explained due to malnutrition can lower the body's defense and disrupt the function of children immune (Rosari, Rini, and Masrul, 2013).

Based on educational level of mother, children whose mother had low educational level tend to suffer diarrhea. Case and Paxson (2001) found that children with more highly educated mothers were more likely to be in excellent or very good health. More-educated parents may be better informed about the availability and use of health care, or have better health behavior that confers benefits to their children. The younger age of mother were found to be significantly proved to affect childhood diarrhea. Papikyan (2009) found that the score of mother's knowledge increase along with the increasing of mother's age, so that the older mother tend to had more children and had gained experience to manage diarrhea effectively than those mother who were younger and less experienced. Based on mother's hand washing practice, the mother who practice improperly hand washing tend to have a children that is more suffer to diarrhea than those who had practiced hand washing properly. Hand washing with soap has been shown to reduce the incidence of diarrheal disease by over 40 per cent (WHO 2009). Hand washing also one of hygiene practices of mother, so that mother which had better hygiene can prevent their children from suffered diarrhea (Rosari, Rini, danMasrul, 2013).

According to access to drinking water source, children whose household had unimproved source of drinking water tend to suffer diarrhea than children with improved source of drinking. Interventions to improve water quality at the source, along with treatment of household water and safe storage systems, have been shown to reduce diarrhea incidence by as much as 47 per cent (WHO, 2009). Improved sanitation also reduced the risk of diarrhea incidence. This can be explained because improvements in sanitation reduce the transmission of pathogens that cause diarrhea by preventing human faecal matter from contaminating environments (WHO, 2009). According to household density, children who lived in dense household had higher risk of suffering diarrhea than children who lived in sparse household. This can be explained due to dense household had a frequent interaction among family members. If one of the family member suffering from diarrhea, then the chain of disease transmission become more shorter so that people become relatively had a higher risk to suffer diarrhea. In addition, the residential density also illustrates how the sanitation in the house is. Houses with relatively dense population density tend to have poor sanitation (Irianto, 2000) 


\section{Conclusion}

The results of this study conclude that diarrhea in Java occurs in children aged 0 to 24 months, has poor nutritional status, has a mother with a low education, has a mother aged 30 years and under, has a mother who washes hands incorrectly, living in Households with poor, unclean access to drinking water, poor sanitation, and live in crowded and unhealthy households. All variables: child age, child nutritional status, mother's education level, mother's age, mother's hand washing practice, access to drinking water sources, access to sanitation and household density have been significantly associated with childhood diarrhea in Java. This study confirms that healthy living habits become a major factor for the occurrence of diarrhea in children, especially for the mother or caregiver. Besides that knowledge about healthy sanitation also become important aspect for mother. Mother that have knowledge about healthy habit would understand how to keep clean of herself and its home to providing healththy enviroment for their children.

\section{References}

Adisasmito,W. (2007). Faktor Risiko Diare pada Bayi dan Balita di Indonesia: Systematic Review Penelitan Akademik Bidang Kesehatan Masyarakat. Makara, Kesehatan, 11(1), 1-10.

BAPPENAS. (2015). Laporan Pencapaian Tujuan Pembangunan Milenium di Indonesia 2014. Jakarta: Badan Perencanaan Pembangunan Nasional.

BPS. (2012). Profil Kesehatan Ibu dan Anak 2012. Jakarta: Badan Pusat Statistik.

Case, A., \& Paxson, C. (2002). Parental Behavior and Child Health. Health Affairs, 21(2), 23-34.

DepkesRI.(2015). Sanitasi dan Air Minum yang Layak Kurangi Resiko Diare Hingga 94\%. $\begin{array}{lllll}\text { Accesed } & \text { on } & 10 & \text { March } & 2016\end{array}$ http://www.depkes.go.id/article/view/15061500001/sanitasi-dan-air-minum-yang-layakkurangi-resiko-diare-hingga-94-.html

Effendy, N.(1998). Dasar-dasar Keperawatan Kesehatan Masyarakat. Diakses pada 22 Mei from https://books.google.co.id/books?id.

Febrianty.(2013).Menginterpretasikan Analisis Regresi Logistik. Diakses pada 1 Juli 2016 from http://news.palcomtech.com/menginterpretasikan-hasil-analisis-regresi-logistik/

Hosmer, D. W. \& Lemeshow, S. (2000). Applied logistic regression second edition. USA: John Wiley \& Sons, Inc.

Irianto (2000). Prediksi frekuensi diare pada anak balita from kepadatan hunian rumah tangga di Indonesia (Analisis data SDKI 1997). (Tesis tidak diterbitkan). Universitas 
Indonesia, Jakarta.

Irianto, M. (1996). Faktor-faktor yang mempengaruhi kejadian diare pada anak balita (Analisis Lanjut Data SDKI 2012). Buletin Penelitian Kesehatan, 24(2\&3), 43-51.

Kemenkes RI. (2011). Situasi Diare di Indonesia. Jakarta: Kementerian Kesehatan RI.

Kemenkes RI. (2014). Profil Kesehatan Indonesia 2013. Jakarta: Kementerian Kesehatan RI.

Kemenkes RI. (2013b). Riset Kesehatan Dasar 2013. Jakarta: Kementerian Kesehatan Republik Indonesia.

Kleinbaum, D. G., \& Klein, M. (2010). Logistic regression a self learning text, third edition. USA: Springer Science Business Media LLC.

Notoatmodjo, S. (2010). Metodologi Penelitian Kesehatan. Jakarta: Rineka Cipta.

Papikyan, S. (2009). The association of maternal knowledge and management with prevalence and duration of childhood diarrheal disease in Yerevan. Journal of Public Health Study, 2(3),67-87.

Rakorpop Kemenkes RI. (2015). Kesehatan dalam kerangka sustainable development goals (SDGS). Jakarta: Kemenkes RI.

Rosari A., Rini, E. A., \& Masrul. (2013). Hubungan diare dengan status gizi balita di Kelurahan Lubuk Buaya Kecamatan Koto Tengah Kota Padang. Jurnal Kesehatan Andalas, 2(3), 54-68.

Shintamurniwathy (2006). Faktor-faktor risiko kejadian diare akut pada balita (Studi Kasus di Kabupaten Semarang). (Tesis tidak diterbitkan). Semarang: Universitas Diponegoro.

Siregar, H., \& Nely, R. (2005). Infrastruktur dasar dan pembiayaannya. AGRIMEDIA, 10(2), 92-116.

WHO. (2009). Diarrhoea: Why children are still dying and what can be done. Switzerland :World Health Organization.

WHO. (2013). Diarrhoe al disease. Accessed on 22 May 2016 from http://www.who.int/mediacentre/factsheets/fs330/en/

Widjaja, M. C. (2002). Mengatasi diare dan keracunan pada balita. Accesed on 5 Mei 2016darihttps://books.google.co.id/books?id= mL2pHvlj5UC\&pg=PR4\&lpg=PR4\&dq =widjaja+diare+balita\&source=bl\&ots=A1kBF48rzy\&sig=LaeVal8WtRZErTR7Kn6Ng d5FizA\&hl=en\&sa=X\&ved=0ahUKEwi3yZTQ 9zOAhXHipQKHXTrCccQ6AEIKDA $\underline{\mathrm{B} \# \mathrm{v}=\text { onepage } \& \mathrm{q}=\text { widjaja\%20diare } \% 20 \mathrm{balita} \& \mathrm{f}=\text { false }}$

Yusuf, S. (2012). Profil diare di ruang rawat inap anak. Sari Pediatri, 13(4), 34-54. 